International Journal of English Literature and Social Sciences
Vol-6, Issue-3; May-Jun, 2021
Journal Home Page Available: https://ijels.com/
Journal DOI: $10.22161 /$ ijels

Peer-Reviewed Journal

\title{
Vocabulary Learning Strategies and Foreign Language Acquisition at Private Schools
}

\author{
Bayad Jamal Ali ${ }^{1}$, Govand Anwar ${ }^{2}$
}

\author{
${ }^{1}$ Business Administration Department, Komar University of Science and Technology, Sulaimani 46001, Kurdistan Region - Iraq \\ ${ }^{2}$ Department of Business Administration, College of Administration and Financial Sciences, Knowledge University, 44001 Erbil, \\ Kurdistan Region, Iraq
}

Received: 09 Mar 2021; Received in revised form: 28 Apr 2021; Accepted: 16 May 2021; Available online: 04 Jun 2021 (C)2021 The Author(s). Published by Infogain Publication. This is an open access article under the CC BY license (https://creativecommons.org/licenses/by/4.0/).

\begin{abstract}
The current research aims to investigate how English Language Learners help their students improve their vocabulary at private university at Kurdistan. Since vocabulary knowledge has a significant role in mastering the new language and in attaining total academic achievement, especially when language is used as a medium of instruction. Students in Kurdistan need English language practically rather than only for fulfilling the academic demand to obtain a certain degree, at the same time in order to help students be successful in practicing English language as a second language they need to gain greater knowledge of the language. Learning vocabulary is an important factor in learning English language, therefore it is very important to address the question of how students build and create their vocabularies, what kind of strategies do they employ in order to learn new vocabulary; therefore the current study is to examine the variety and range of vocabulary learning strategies among students. The findings of this study revealed that (Memory, Cognitive, metacognitive and social) strategies had positive relation with self-regulatory capacities in vocabulary learning. The highest value was for social strategy $(B=.547)$, accordingly social strategy had a strong positive relationship with self-regulatory capacity in vocabulary learning.
\end{abstract}

Keywords - Vocabulary Learning Strategies, Foreign Language Acquisition, Kurdistan.

\section{INTRODUCTION}

English language is considered as a foreign language in Kurdistan (Abdullah et al. 2021), English is an important language for many students in private universities at Kurdistan as students do not have an access to English language except what they are learning in school (Ahmed et al. 2021). Students in Kurdistan have to attend classroom and maintain their day-to-day activities to successfully respond to their academic demands (Akoi et al. 2021). English language should be considered as an important international language this may bring possibilities for students to give more attention and their interest to English language (Ali \& Anwar, 2021). This means students in Kurdistan need practically English language rather than only for fulfilling the academic demand to obtain a certain degree, at the same time in other students be successful in practicing English language (Ali et al. 2021)as a second language they need to help of great knowledge of the language (Ali, 2014). Furthermore, students should be provided with available opportunities for learning English language in school through writing (Andavar et al. 2020), reading and conversation skills and improve individual student's language skills (Anwar \& Abd Zebari, 2015). Vocabulary considers an essential factor in English language, without vocabulary learning the English language is almost impossible. Some of scholars think that vocabulary learning is not difficult (Anwar \& Abdullah, 2021), but vocabulary learning is very challenging for learners (Anwar \& Balcioglu, 2016). This research investigates the variety and range of vocabulary learning strategies in private universities in Kurdistan (Anwar \& Climis, 2017). In order being able to understand the process of vocabulary learning (Anwar \& Ghafoor,2017), we should 
think outside of the box and address main factors that have influence on learning vocabulary (Anwar \& Qadir, 2017).

\section{Vocabulary Learning Strategies}

At the present time, there has been a huge change of concentration from the traditional education provider dominated method to a student-centered method of vocabulary acquisition (Anwar \& Shukur, 2015). The traditional method for education providers in terms of vocabulary teaching has regularly been evaluated, concerning many other things (Anwar \& Surarchith, 2015), it is important to address the significance of the student's involvement and engagement in the process (Anwar, 2016). The main discussion in this matter has been that students are not frequently motivated to provide their own possible for the fruitful growth of their vocabulary and other competencies (Anwar, 2017). Instead, students are relying on education providers, getting whatever learning from education providers. According to (Anwar, K., \& Louis, 2017), Learning vocabulary is a very challenging process in teaching second language (Aziz et al. 2021).

\section{Classification of Vocabulary Learning Strategies}

Many academic scholars have classified learning strategies in different ways. For instance, (Demir et al. 2020) suggested five broad strategy categories and some secondary categories (Faraj et al. 2021). (Hameed \& Anwar, 2018)classified learning strategies into two main groups, namely, strategies which participate straight to learning and those which participate secondarily to learning (Hamza et al. 2021). (Ismael et al. 2021), identified three categories of strategies which they named cognitive, metacognitive, and social-affective (Abdullah et al. 2021). Oxford (1990) advanced a complete taxonomy by assembling and rearranging strategies recognized in earlier researches (Ahmed et al. 2021). Oxford taxonomy collections the complete set of learning strategies into two broad categories: direct and indirect strategies (Akoi et al. 2021).

\section{Direct Strategies}

According to the (Ali \& Anwar, 2021), strategies are directly participating the learning of the language through directly linking the student in performing on the second language. Direct strategies consist of memory strategies and cognitive strategies (Ali et al. 2021).

- Memory Strategies

Based on the name itself indicates, strategies assist students to recall and remember vocabulary efficiently and effectively. Memory strategies consist of the following (Ali, 2014):

- Grouping - gathering the words to be educated in an expressive way (for instance, gathering words together based on parts of speech, subject relationship and dissimilarity and similarity in meaning. Etc.) (Andavar et al. 2020).

- Correlating/Elaborating- this happens by linking new vocabulary to another thing similar in mind, building connection in a meaningful way to enable memory (Anwar \& Abd Zebari, 2015)(for example, recalling the new words through imagining the page number or location of the number in that page) (Anwar \& Abdullah, 2021).

\section{Cognitive Strategies}

- According to (Anwar \& Balcioglu, 2016), Cognitive strategies are used by students while directly performing on the target language (Anwar $\&$ Climis, 2017). Cognitive strategies indicate two phases used in problem solving or learning that need direct examination and conversation (Anwar $\&$ Ghafoor,2017). The main cognitive strategies are: Repeating - writing or saying the new words again, listening to the same words numerous times; copying experienced users of English (Anwar \& Qadir, 2017).

- Using Resources for Receiving Messages - using language reference resources, for example the dictionary or requesting someone to help with the meaning of uncommon words (Andavar et al. 2020).

- Reasoning deductively- determinedly using overall procedures to work out the meaning of uncommon vocabulary (for instance, working out the meaning of 'dissatisfy' from the meaning of the prefix 'dis-' and the meaning of the adjective 'satisfy') (Anwar \& Abd Zebari, 2015).

- Translating- shifting the meaning of language, word into a comparable meaning of mother-tongue language (Anwar \& Abdullah, 2021).

- Transferring - using earlier learned information of words from one language to recognize the meaning of the new language words (Anwar \& Balcioglu, 2016).

- Highlighting - coloring or highlighting the essential words while reading the text and finding their meanings (Anwar \& Climis, 2017).

\section{Indirect Strategies}

Indirect strategies include strategies which indirectly participate in the expansion of vocabulary (Anwar \& Ghafoor,2017). Strategies do not frequently need the students to directly effort on the target language tasks, however, they help them to achieve and enable their learning in a different ways through building for them positive learning circumstances (Anwar \& Qadir, 2017). Indirect strategies consist of the following two groups of 
strategies: metacognitive and social strategies (Anwar \& Shukur, 2015).

\section{- Metacognitive Strategies}

Strategies used by students to achieve themselves through controlling performance (Anwar \& Surarchith, 2015), planning and assessing general development or the consequence of their learning (Anwar, 2016). Metacognitive strategies include students in (Anwar, 2017):

- Over viewing and Connecting with previously recognized Material- over viewing widely the key vocabulary matters to be learned in future vocabulary instructions and connecting them with the words previously learned (Anwar, K., \& Louis, 2017).

○ Paying Attention- making decision in advance to imitate to one's vocabulary learning in general and to choose and concentrate on related vocabulary tasks (Anwar \& Abd Zebari, 2015).

○ Organizing - building satisfactory physical environment to enable student's vocabulary learning; brainwashing student's vocabulary learning (Anwar \& Abdullah, 2021).

- Self - Monitoring - classifying student's mistakes in the sequence of vocabulary learning by examining whether one is learning properly or incorrectly (Anwar \& Balcioglu, 2016).

- Self-Evaluating-assessing the consequences of students' vocabulary learning (Anwar \& Climis, 2017).
- Social Strategies Social Strategies are strategies which contain of using social connections to help learning (Anwar \& Qadir, 2017). Meanwhile language learning includes other people too; students do not usually perform it all alone (Anwar \& Ghafoor,2017). Social strategies include learners in (Oxford 1990):

- Cooperating with Proficient Users of English - being friends with proficient speakers of English to enhance one's information of English vocabulary.

- Developing Cultural Understandingsexpanding one's thoughtful of the culture and ways of living of English speaking people.

Foreign Language Acquisition

It provides new chances to students' strategic learning and assists them in order to be self-directed and independent learners (Anwar \& Shukur, 2015). Also, it concentrates on the significance of the regulatory capacity in the students' efforts to apply specific strategy for vocabulary learning (Anwar \& Surarchith, 2015). Self-regulation is not only concentrated on the consequences students' achievement, however, essentially in the process students go through and the way that effects vocabulary learning (Anwar, 2016). Previous scholars believed that quantity such us applying different strategies based on learners' level of learning (Anwar, 2017).

Conceptual framework

Research model and research hypothesis

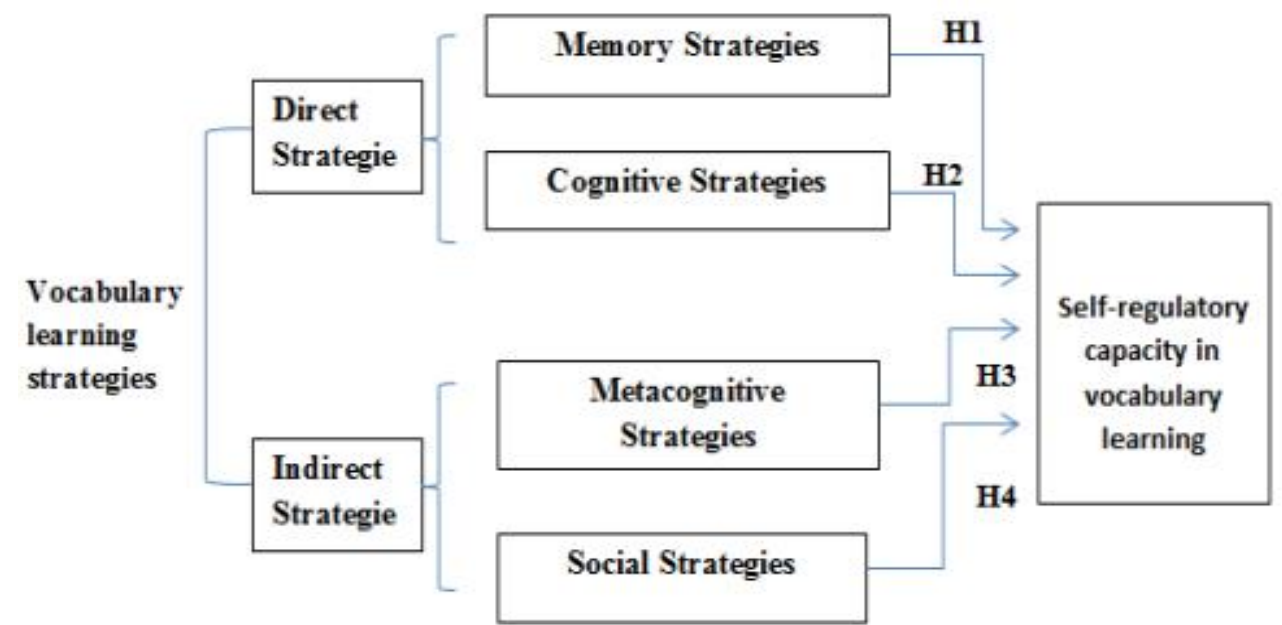

Independent factors

Dependent factor

Fig. 1: Research Mode, Created by the researchers 
According to the created research model, the researcher developed the following research hypothsis:

H1: There is a positive relationship between memeory strategy and Foreign Language Acquisitionin vocabulary learning.

$\mathrm{H} 2$ : There is a positive relationship between cognitive strategy and Foreign Language Acquisitionin vocabulary learning.

H3: There is a positive relationship between metagocnitive strategy and Foreign Language Acquisitionin vocabulary learning.

H4: There is a positive relationship between social strategy and Foreign Language Acquisitionin vocabulary learning.

\section{METHODOLOGY}

Quantitative method was used to analyze the data in this study, the researcher prepared questionnaire and distributed in English language department in the private university at Kurdistan. The survey was divided into two sections, the first section was demographic analysis which started with respondent's age, gender, and level of education. The second section of survey consisted of 28 questions regarding strategies of vocabulary learning. A random sampling method was used in this study. The researcher, distributed 140 questionnaires, 115 questionnaires were received and being completed properly and 25 questionnaires were missing. Students were varied as for age, gender and level of education. In order to examine the students' vocabulary learning strategies, the participants were asked to mark each item for five point ordered scale. The scale measured and evaluated on a five point Likert Scale with potential answers ranging from strongly disagree to strongly agree, this research instruments were validated by earlier researchers (Samaneh. 2012) and (Tseng,2006) to be appropriate for measuring vocabulary learning strategies in self-regulatory capacity in learning vocabulary.

III. DATA ANALYSIS AND RESULTS

Table -1-Demographic analysis

\begin{tabular}{lccc}
\hline Item & & Frequency & Percent \\
\hline \multirow{4}{*}{ Age } & $18-19$ & 54 & 47.0 \\
& $20-21$ & 36 & 31.3 \\
& $22-23$ & 14 & 12.2 \\
Gender & $24-25$ & 11 & 9.6 \\
& Male & 73 & 63.5 \\
education & Female & 42 & 36.5 \\
& First year & 39 & 33.9 \\
& Second year & 29 & 25.2 \\
& Third year & 22 & 19.1 \\
& Fourth year & 25 & 21.7 \\
\hline
\end{tabular}

As seen in table (1), participants' personal information. As for student's gender; 54 students were male and 36 students were female. As for age 54 students fall into group 18-19 years old, 36 students fall into group 20-22years old, 14 students fall into group 22-23 years old and 11 students fall into group 24-25 years old. As for level of education 39 students from first year, 29 students from second year, 22 students from third year and 25 students from fourth year. 
Table -2- Reliability analysis

\begin{tabular}{lcc}
\hline Variable & $\begin{array}{c}\text { Cronbach's } \\
\text { Alpha }\end{array}$ & $\begin{array}{l}\text { Number } \\
\text { items }\end{array}$ \\
\hline Memory strategy & .857 & 7 \\
Cognitive strategy & .766 & 6 \\
Metacognitive strategy & .935 & 7 \\
Social strategy & .921 & 8 \\
Self-regulatory capacity strategy in & .973 & 8 \\
vocabulary learning & & \\
\hline
\end{tabular}

As seen in table (2), the reliability analysis for vocabulary learning strategies as independent factor (memory strategy, cognitive strategy, metacognitive strategy and social strategy), on the other hand self-regularoty capacity in vocabulary learning as a dependent factor. According to the correlation analysis, the researcher found out Cronbach's Alpha for the seven items used for memory strategy factor $=.857$, which is greater than .6 this means that items for memory strategy factor were reliable for this study, the Cronbach's Alpha for six items for cognitive strategy factor $=.766$, which is greater than .6 this means that items for cognitive strategy factor were reliable for this study, the
Cronbach's Alpha for seven items of metacognitive strategy factor $=.935$, which is greater than .6 this means that items for etacognitive strategy factor were reliable for this study, the Cronbach's Alpha for eight items of social strategy factor $=.921$, which is greater than .6 this means that items for social strategy factor were reliable for this study and the Cronbach's Alpha for eight items for self-regulatory capacity strategy in vocabulary learning factor $=.973$, which is greater than .6 this means that items of self-regulatory capacity strategy in vocabulary learning factor were reliable for this study.

Table-3 Correlations analysis

\begin{tabular}{|c|c|c|c|c|c|}
\hline \multicolumn{6}{|c|}{ Correlations } \\
\hline \multirow{4}{*}{$\begin{array}{l}\text { Self- } \\
\text { regula } \\
\text { tory }\end{array}$} & & $\begin{array}{c}\text { memo } \\
\text { ry }\end{array}$ & $\begin{array}{c}\text { Cogniti } \\
\text { ve }\end{array}$ & Social & $\begin{array}{l}\text { Metacog } \\
\text { nitive }\end{array}$ \\
\hline & Pearson & $.208^{* *}$ & $.198^{* *}$ & $.368^{* *}$ & $.058^{* *}$ \\
\hline & $\begin{array}{l}\text { Correlatio } \\
\mathrm{n}\end{array}$ & & & & \\
\hline & $\begin{array}{l}\text { Sig. (2- } \\
\text { tailed) }\end{array}$ & .026 & .033 & .000 & .538 \\
\hline & $\mathrm{N}$ & 115 & 115 & 115 & 115 \\
\hline
\end{tabular}

Regression analysis

Table-4-Model Summary

\begin{tabular}{|c|c|c|c|c|}
\hline \multicolumn{5}{|c|}{ Model Summary } \\
\hline Model & $\mathrm{R}$ & R Square & Adjusted R Square & $\begin{array}{l}\text { Std. Error of } \\
\text { the Estimate }\end{array}$ \\
\hline $\mathbf{1}$ & $.405^{\mathrm{a}}$ & .164 & .134 & 1.25505 \\
\hline
\end{tabular}




\begin{tabular}{|c|c|c|c|c|c|}
\hline \multicolumn{6}{|c|}{$\begin{array}{c}\text { Table-4- } \\
\text { ANOVA }^{\mathrm{a}}\end{array}$} \\
\hline & & Sum of Squares & df & Mean Square & $\mathrm{F}$ \\
\hline \multirow[t]{3}{*}{1} & Regression & 34.079 & 4 & 8.520 & 5.409 \\
\hline & Residual & 173.266 & 110 & 1.575 & \\
\hline & Total & 207.345 & 114 & & \\
\hline & $\begin{array}{l}\text { ndent Varia } \\
\text { ictors: (Con }\end{array}$ & $\begin{array}{l}\text { self-regulatory } \\
\text {, social, memor, }\end{array}$ & gniti & ognitive & \\
\hline
\end{tabular}

Table-5- Coefficients

\begin{tabular}{|c|c|c|c|c|c|c|}
\hline \multicolumn{7}{|c|}{ Coefficients $^{\mathrm{a}}$} \\
\hline & & $\begin{array}{r}\text { Uns } \\
\mathrm{C}\end{array}$ & $\begin{array}{l}\text { dardized } \\
\text { icients }\end{array}$ & $\begin{array}{c}\text { Standar } \\
\text { dized }\end{array}$ & $\mathrm{t}$ & Sig. \\
\hline & & B & Std. Error & Beta & & \\
\hline \multirow[t]{5}{*}{$\mathbf{1}$} & $\begin{array}{l}\text { (Constant } \\
\text { ) }\end{array}$ & -.305 & .885 & & -.344 & .731 \\
\hline & Memory & .271 & .148 & .175 & 1.832 & .070 \\
\hline & Cognitive & .024 & .175 & .018 & .139 & .889 \\
\hline & $\begin{array}{l}\text { Metacogn } \\
\text { itive }\end{array}$ & .019 & .144 & .012 & .131 & .896 \\
\hline & Social & .547 & .197 & .336 & 2.774 & .006 \\
\hline & endent Var & : self- & ulatory cap & & & \\
\hline
\end{tabular}

Table (5), shows the coefficients analysis for this study. As seen in the above table the value B for memeory strategy $=.271<0.01$, accordingly the first research hypothesis was supported. The value B for cognitive strategy $=0.24<0.01$, accordingly the second research hypothesis was supported. The value B for memory strategy $=0.19<0.01$, accordingly the third research hypothesis was supported and the value $B$ for social strategy $=0.547<0.01$ accordingly the fourth research hypothesis was supported.

\section{DISCUSSIONS}

The current study aims to investigate the vocabulary learning strategies and how students learn and adopt their vocabulary information, since vocabulary knowledge has a significant role in mastering the new language and in attaining total academic achievement when that language is used as a medium of instruction. Quantitative methods used to analyze this study, the researcher prepared a questionnaire and distributed at English language department in private university at Kurdistan. The researcher used multiple regression analysis, accordingly all research hypothesis were supported. The highest value was 
for social strategy $(B=.547)$. Previous studies found the positive effect of vocabulary learning strategies (cognitive, memory, meta-cognitive and social strategy on teaching second language ( (Abhakorn, 2008), (Doczi, 2011), (Folse, 2004), (Hung-Tzu, 2007), (Sedita, 2005), (Shea, 2011), (Winke and Sydorenko, 2010) ).

\section{A. Cognitive strategy:}

Students prefer to use a bilingual dictionary to translate English words into their mother tangue language; this indicates that teachers should rely on cognitive strategy to teach vocabulary to their students such as using language reference resources. When students find a new word while they are in the classroom, they would ask their teacher to put that word ina sentence in order to assist them to memorize and understand the meaning of that word. Students would like to listen to news and songs in order to enhance their English language, this indicates that teachers should use a cognitive strategy such as using Resources for Receiving Messages - using language reference resources, for example the dictionary or requesting someone to help with the meaning of uncommon words. Students use English magazine to learn new English vocabulary, this indicates that teacher should use a cognitive strategy such as using Resources for Receiving Messages - using language reference resources, for example the dictionary or requesting someone to help with the meaning of uncommon words. In case a new word comes across students would guess from context, this means the teacher should use a cognitive such as Highlighting - coloring or highlighting the essential words while reading the text and finding their meaning. When a new word comes across, while class they would refer to ask their teacher, therefore; the teacher should apply a cognitive strategy such as usingresources for receiving messages - using language reference resources, for example the dictionary or requesting someone to help with the meaning of uncommon words. In case a new word comes across, while they are at home, they would use bilingual dictionary, so teachers should use a cognitive strategy such as using resources for receiving messages using language reference resources, for example the dictionary or requesting someone to help with the meaning of uncommon words. When a new word comes across, while students are at home, they would use an online dictionary, so teachers should use a cognitive strategy such as using resources for receiving messages - using language reference resources, for example the dictionary or requesting someone to help with the meaning of uncommon words. Students use an online dictionary to find out the pronunciation of new vocabulary and students learn new vocabulary from their teachers, so teachers should use cognitive strategy, according to this results teacher should use cognitive strategy such as using Resources for
Receiving Messages - using language reference resources, for example the dictionary or requesting someone to help with the meaning of uncommon words. Students repeat the new word several times in their mind to memorize it and they are repeating new words loudly for several times in their mind in order to be able to memorize it. Based on this results teacher should apply a cognitive strategy such us repeating - writing or saying the new words again, listing with the same words numerous times; copying experienced users of English. Students are using the definition of new words in order to be able to understand and memorize it, in this case teacher should use cognitive strategy such as Using Resources for Receiving Messages - using language reference resources for example the dictionary or requesting someone to help with the meaning of uncommon words. Students take notes when they learn new vocabulary; TV programs help students to learn new words, Listening to radio help students to learn new words, students read English newspaper regularly, Online vocabulary learning activities helps students to learn new words and Students are not satisfied with English materials and methods in their classes, based on these results teacher should use a cognitive strategy such as using resources for receiving messages - using language reference resources, for example the dictionary or requesting someone to help with the meaning of uncommon words. Therefore, the researcher came to conclude that research hypothesis, one has been supported, there is a positive association between cognitive strategy and vocabulary learning strategies.

\section{B. Metacognitive:}

When students work as groups in their classroom, they will learn new words from their classmates, according to this result, it seems that students are comfortable working in a group, therefore teachers should use meta-cognitive strategy in order to teach their students, as mentioned that meta-cognitive strategy is organizing - building satisfactory physical environment to enable student's vocabulary learning; brainwashing student's vocabulary learning. Physical actions help students to learn new word, based on this result, teachers should use meta-cognitive strategy such as organizing - building satisfactory physical environment to enable student's vocabulary learning; brainwashing student's vocabulary learning. Students are skipping a new word that comes across while they are home, according to these results the teacher should apply metacognitive strategy such as a self - monitoring - classifying student's mistakes in the sequence of vocabulary learning by examining whether one is learning properly or incorrectly. Students learn new vocabulary when their teacher shows them their mistakes, according to this result, teachers should use a meta-cognitive strategy such as self - monitoring classifying student's mistakes in the sequence of vocabulary 
learning by examining whether one is learning properly or incorrectly. Students revise new words that they have learnt in class, therefore the teacher should apply meta-cognitive strategy such as over viewing and connecting with the previously recognized material over viewing widely the key vocabulary matters to be learned in future vocabulary. Students learn new vocabulary in certain situation and they learn new vocabulary from their classmates, according to these results the teacher should apply a meta-cognitive strategy such as organizing - building satisfactory physical environment to enable student's vocabulary learning; brainwashing student's vocabulary learning. Therefore, the researcher came to conclude that research hypothesis two has been supported; there is a positive association between metacognitive strategy and vocabulary learning strategies.

\section{Social:}

Based on the statistical results of the questionnaire, it seems that students do not refer and speak to English speaker when they do not know a particular word, the reason could be the lack of the English speakers in Kurdistan. At this point the teacher should encourage their students to be involved in English cultural events if it is possible, therefore the teacher should use a social strategy which means cooperating with proficient users of English - being friends with proficient speakers of English to enhance one's information of English vocabulary. In case the new word comes across, while students are in the class they would prefer to ask their classmates, according to this result, teachers should use and encourage a social strategy, grouping students in the classroom to enhance their vocabulary and learn new vocabulary, developing cultural understandings-expanding one's thoughtful of the culture and ways of living of English speaking people. Students prefer to imitate someone's vocabulary in order to learn, consequently, teachers should use social strategy such as cooperating with proficient users of English- being friends with proficient speakers of English to enhance their information of English vocabulary. Well physical environment helps students to quick learning, this means that the teacher should apply social strategy such as developing cultural understandings and expanding their understanding of the culture and English speaking peoples ways of living. Students prefer to be involved in English culture speakers in order to learn new vocabularies, this means that the teacher should apply a social strategy, for instance; developing cultural understandings and expanding their understanding of the target culture and ways of living of English speaking people. Therefore, the researcher came to conclude that research hypothesis 3 has been supported; there is a positive association between social strategy and vocabulary learning strategies.

\section{Memory}

Students would like to use images in order to demonstrate in the textbook to find the word meanings, this indicates that teachers should use memory strategy such as Correlating/Elaborating- by linking new vocabulary to another thing similar in mind, building connection in a meaningful way to enable memory for example, recalling the new words through imagining the page number or location of the number in that page. Students would like to put a new word into a sentence as an example to be able to memorize new words. In this case the teacher should use memory strategy such as Correlating/Elaborating- by linking new vocabulary to another thing similar in mind, building connection in a meaningful way to enable memory (for example, recalling the new words through imagining the page number or location of the number in that page. Students write down words to memorize them, they are matching example with new words in order to memorize them and students are using images and pictures to memorize new word, according to this result, teachers should use memory strategy such as correlating/Elaborating- linking new vocabulary to another thing similar in mind, building connection in a meaningful way to enable memory (for example, recalling the new words through imagining the page number or location of the number in that page. Students are trying to memorize a word and remember it through a song or a text and when they find a new word they would match it with another similar word in order to be able to memorize it; therefore, teachers should use memory strategy. Therefore, the researcher came to conclude that the research hypothesis four has been supported; there is a positive association between memory strategy and vocabulary learning strategies.

\section{REFERENCES}

[1] Top, C., \& Ali, B. J. (2021). Customer satisfaction in online meeting platforms: Impact of efficiency, fulfillment, system availability, and privacy. Amazonia Investiga, 10(38), 7081. https://doi.org/10.34069/AI/2021.38.02.7

[2] Demir, A., Maroof, L., Sabbah Khan, N.U. and Ali, B.J. (2020), "The role of E-service quality in shaping online meeting platforms: a case study from higher education sector", Journal of Applied Research in Higher Education. https://doi.org/10.1108/JARHE-08-2020-0253

[3] Ali, B, J. (2021). Impact of consumer animosity, boycott participation, boycott motivation, and product judgment on purchase readiness or aversion of Kurdish consumers in Iraq. Journal of Consumers Affaires; 1-20. https://doi.org/10.1111/joca.12350

[4] Ali, B, J. (2020). Impact of COVID-19 on consumer buying behavior toward online shopping in Iraq. Economic studies journal. 18(42): 267-280. Retrieved from https://www.asjp.cerist.dz/en/article/134070 
[5] Ali, B.J. (2021) Assessing (The impact) of advertisement on customer decision making: Evidence from an educational institution. Afak for sciences journal, 6(1): 425-439. Retrieved from https://www.asjp.cerist.dz/en/article/141056

[6] Ali, B.J. (2021) Consumer attitudes towards healthy and organic food in the Kurdistan region of Iraq. Management Science Letters. 11: 1-8. DOI: 10.5267/j.msl.2021.2.015

[7] Andavar, V., Ali, B.J., and Ali, S.A. (2020) Rainwater for Water Scarcity Management: An Experience of Woldia University (Ethiopia). Journal of Business, Economics and Environmental Studies, 10-(4): 29-34. DOI: 10.13106/jbees.2020.vol10.no4.29

[8] Faraj, K. M., Faeq, D. K., Abdulla, D. F., Ali, B. J., \& Sadq, Z. M. (2021). Total Quality Management And Hotel Employee Creative Performance: The Mediation Role Of Job Embeddedment. Journal of Contemporary Issues in Business and Government, 27(1), 3838-3855. http://dx.doi.org/10.47750/cibg.2021.27.01.001

[9] Ali, B. J. (2016). Iraq Stock Market and its Role in the Economy. Retrieved from https://www.amazon.com/IraqStock-Market-Role-Economy/dp/3659634271

[10] Ali, B. J. (2014). Brand Building in the Consumer Electronics Industry in Iraq. Retrieved from https://www.amazon.com/Brand-Building-ConsumerElectronics-Industry/dp/6200248699

[11] Ali, B. J., \& Anwar, G. (2021). Factors Influencing the Citizens' Acceptance of Electronic Government. International Journal of Engineering, Business and Management, $\quad 5(1), \quad 48-60$. https://doi.org/10.22161/ijebm.5.1.5

[12] Saleh, P. F., Ali, B. J., Akoi, S., Najmalddin, B., Ali, R. S., $\&$ Anwar, G. (2021). Factors affecting the Success of Female Entrepreneurs in Kurdistan. International journal of Engineering, Business and Management (IJEBM), 5.

[13] Ali, B. J., \& Anwar, G. (2021). The Effect of Marketing Culture Aspects of Healthcare Care on Marketing Creativity. International Journal of English Literature and Social Sciences, 6(2), 171-182. https://doi.org/10.22161/ijels.62.25

[14] Ali, B. J., \& Anwar, G. (2021). An Empirical Study of Employees' Motivation and its Influence Job Satisfaction. International Journal of Engineering, Business and Management, 5(2), 21-30. https://doi.org/10.22161/ijebm.5.2.3

[15] Ali, B. J., Saleh, P. F., Akoi, S., Abdulrahman, A. A., Muhamed, A. S., Noori, H. N., \& Anwar, G. (2021, May). Impact of Service Quality on the Customer Satisfaction: Case study at Online Meeting Platforms. In Ali, BJ, Saleh, Akoi, S., Abdulrahman, AA, Muhamed, AS, Noori, HN, Anwar, G.(2021). Impact of Service Quality on the Customer Satisfaction: Case study at Online Meeting Platforms. International journal of Engineering, Business and Management (Vol. 5, No. 2, pp. 65-77).

[16] Ali, B. J., \& Anwar, G. (2021). The balanced scorecard's evolution as a strategic mechanism at banking sectors. International Journal of English Literature and Social Sciences, $\quad 6(1), \quad 471-478$. https://doi.org/10.22161/ijels.61.63
[17] Anwar, G., \& Abdullah, N. N. (2021). Inspiring future entrepreneurs: The effect of experiential learning on the entrepreneurial intention at higher education. International Journal of English Literature and Social Sciences, 6.

[18] Ali, B. J., \& Anwar, G. (2021). Measuring competitive intelligence Network and its role on Business Performance. International Journal of English Literature and Social Sciences, 6(2), 329-345. https://dx.doi.org/10.22161/ijels.62.50

[19] Anwar, G., \& Abdullah, N. N. (2021). The impact of Human resource management practice on Organizational performance. International journal of Engineering, Business and Management (IJEBM), 5.

[20] Abdullah, N. N., \& Anwar, G. (2021). An Empirical Analysis of Natural Gas as an Alternative Fuel for Internal Transportation. International Journal of English Literature and Social Sciences, 6(1).

[21] Ali, B. J., \& Anwar, G. (2021). A study of knowledge management alignment with production management: A study of carpet manufacture in Kurdistan region of Iraq. International Journal of English Literature and Social Sciences, 6(2), 346-360. https://dx.doi.org/10.22161/ijels.62.51

[22] Ali, B. J., \& Anwar, G. (2021). The mediation role of change management in employee development. International Journal of English Literature and Social Sciences, 6(2), 361374. https://dx.doi.org/10.22161/ijels.62.52

[23] Anwar, K., \& Louis, R. (2017). Factors Affecting Students' Anxiety in Language Learning: A Study of Private Universities in Erbil, Kurdistan. International Journal of Social Sciences \& Educational Studies, 4(3), 160.

[24] Ali, B. J., \& Anwar, G. (2021). Business strategy: The influence of Strategic Competitiveness on competitive advantage. International Journal of Electrical, Electronics and Computers, 6(2), 1-10. https://dx.doi.org/10.22161/eec.62.1

[25] Anwar, K. (2017). Leading Construction Project Teams: The Effectiveness of Transformational Leadership in Dynamic Work Environments in Kurdistan. International Journal of Advanced Engineering, Management and Science, 3(10), 239925.

[26] Ali, B. J., \& Anwar, G. (2021). Strategic leadership effectiveness and its influence on organizational effectiveness. International Journal of Electrical, Electronics and Computers, 6(2), 11-24. https://dx.doi.org/10.22161/eec.62.2

[27] Anwar, K., \& Qadir, G. H. (2017). A Study of the Relationship between Work Engagement and Job Satisfaction in Private Companies in Kurdistan. International Journal of Advanced Engineering, Management and Science, 3(12), 239944.

[28] Ali, B. J., \& Anwar, G. (2021). Intellectual capital: A modern model to measure the value creation in a business. International journal of Engineering, Business and Management, 5(2), 31-43. https://dx.doi.org/10.22161/ijebm.5.2.4

[29] Ali, B. J., \& Anwar, G. (2021). Marketing Strategy: Pricing strategies and its influence on consumer purchasing 
decision. International journal of Rural Development, Environment and Health Research, 5(2), 26-39. https://dx.doi.org/10.22161/ijreh.5.2.4

[30] Anwar, K. (2017). Factors Affecting Stock Exchange Investment In Kurdistan. The International Journal of Accounting and Business Society, 25(1), 32-37.

[31] Ali, B. J., \& Anwar, G. (2021). Organization citizenship behaviour as a determining Factor in Business outcome. International journal of Rural Development, Environment and Health Research, 5(2), 17-25. https://dx.doi.org/10.22161/ijreh.5.2.3

[32] Anwar, K., \& Climis, R. (2017). Analyzing the relationship between types of advertisement and customer choice: a study of retailer stores in erbil. The International Journal of Accounting and Business Society, 25(2), 43-52.

[33] Talim, S.R., Ali, B.J., Top, C. (2021). Elaborating the Antecedents of Purchase Intentions in Second-Hand Car Industry: Case Study in Kurdistan Region of Iraq. Journal of Contemporary Issues in Business and Government, 27(3), 1526-1547. http://dx.doi.org/10.47750/cibg.2021.27.03.204

[34] Anwar, K., \& Ghafoor, C. (2017). Knowledge management and organizational performance: A study of private universities in Kurdistan. International Journal of Social Sciences \& Educational Studies, 4(2), 53.

[35] Ali, B. J., Saleh, Akoi, S., Abdulrahman, A. A., Muhamed, A. S., Noori, H. N., Anwar, G. (2021). Impact of Service Quality on the Customer Satisfaction: Case study at Online Meeting Platforms. International journal of Engineering, Business and Management, 5(2), 65-77. https://dx.doi.org/10.22161/ijebm.5.2.6

[36] Hameed, A. A., \& Anwar, K. (2018). Analyzing the Relationship between Intellectual Capital and Organizational Performance: A Study of Selected Private Banks in Kurdistan. International Journal of Social Sciences \& Educational Studies, 4(4), 39.

[37] Jamal Ali, B., Akoi, S., Fadel Saleh, P., \& Sardar, zhilwan. (2021). Factors Shaping Customer Satisfaction with Residential Flats: Evidence from Sulaymaniyah City. Black Sea Journal of Management and Marketing, 2(2), 1-12. https://doi.org/10.47299/bsjmm.v2i2.69

[38] Akoi, S., Jamal Ali, B., Fadel Saleh, P., Najmalddin, B., Sabah Mustafa, R., Rzgar Abdulmajid, M., \& Rebwar Hama, A. (2021). Elaborating the Characteristics that Affect Buyers in Online Shopping: The Case of Generation Z Girls in Kurdistan Region of Iraq. Black Sea Journal of Management

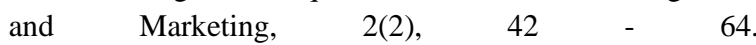
https://doi.org/10.47299/bsjmm.v2i2.74

[39] Anwar, K. (2017). The Role of Effective Leadership in Crisis Management: Study of Private Companies in Kurdistan. Qalaai Zanist Scientific Journal, 2(4), 326-338.

[40] Ahmed, S. Y., Ali, B. J., Top, C. (2021). Understanding the Impact of Trust, Perceived Risk, and Perceived Technology on the Online Shopping Intentions: Case Study in Kurdistan Region of Iraq. Journal of Contemporary Issues in Business and Government, 27(3), 2136-2153. http://dx.doi.org/10.47750/cibg.2021.27.03.264

[41] Anwar, K., \& Balcioglu, H. (2016). The relationship between transformational leadership characteristics and effectiveness: A case study of construction companies in Erbil. International Journal of Science Technology and Management, 5(2), 250-256.

[42] Sabir, B. Y., Othman, B .J., Gardi, B., Ismael, N. B., Hamza, P. A., Sorguli, S., Aziz, H. M., Ahmed, S. A., Ali, B. J., Anwar, G. (2021). Administrative Decentralization: The Transfer of Competency from The Ministry of Education to General Directorates. International Journal of Rural Development, Environment and Health Research, 5(3), 113. https://doi.org/10.22161/ijreh.5.3.1

[43] Abdullah, M. S., Toycan, M., \& Anwar, K. (2017). The cost readiness of implementing e-learning. CUSTOS E AGRONEGOCIO ON LINE, 13(2), 156-175.

[44] Ali, B. J., Anwar, G., Gardi, B., Othman, B. J., Aziz, H. M., Ahmed, S. A., Hamza, P. A., Ismael, N. B., Sorguli, S., Sabir, B. Y. (2021). Business Communication Strategies: Analysis of Internal Communication Processes. Journal of Humanities and Education Development, 3(3), 16-38. https://doi.org/10.22161/jhed.3.3.4

[45] Anwar, K. (2016). Comparison between cost leadership and differentiation strategy in agricultural businesses. Custos E Agronegocio on Line, 12(2), 212-231.

[46] Ali, B. J., Gardi, B., Othman, B. J., Ismael, N. B., Sorguli, S., Sabir, B. Y., Ahmed, S. A., Hamza, P. A., Aziz, H. M., Anwar, G. (2021). Educational system: The policy of Educational system in Kurdistan Region in public Kindergarten. International Journal of English Literature and Social Sciences, 6(3), 062-071. https://doi.org/10.22161/ijels.63.10

[47] Anwar, K. (2017). Analyzing the conceptual model of service quality and its relationship with guests'satisfaction: a study of hotels in erbil. The International Journal of Accounting and Business Society, 25(2), 1-16.

[48] Aziz, H. M., Othman, B. J., Gardi, B., Ahmed, S. A., Sabir, B. Y., Ismael, N. B., Hamza, P. A., Sorguli, S., Ali, B. J., Anwar, G. (2021). Employee Commitment: The Relationship between Employee Commitment And Job Satisfaction. Journal of Humanities and Education Development, 3(3), 54-66. https://doi.org/10.22161/jhed.3.3.6

[49] Anwar, G., \& Shukur, I. (2015). The Impact of Service Quality Dimensions on Students' Satisfaction. International Journal of Social Sciences \& Educational Studies, 76.

[50] Ali, B. J., Gardi, B., Othman, B. J., Ahmed, S. A., Ismael, N. B., Hamza, P. A., Aziz, H. M., Sabir, B. Y., Anwar, G. (2021). Hotel Service Quality: The Impact of Service Quality on Customer Satisfaction in Hospitality. International Journal of Engineering, Business and Management, 5(3), 14-28. https://doi.org/10.22161/ijebm.5.3.2

[51] Anwar, G., \& Surarchith, N. K. (2015). Factors Affecting Shoppers' Behavior in Erbil, Kurdistan-Iraq. International Journal of Social Sciences \& Educational Studies, 1(4), 10.

[52] Sorguli, S., Gardi, B., Othman, B.J., Aziz, H. M., Ahmed, S. A., Sabir, B. Y., Ismael, N. B., Hamza, P. A., Ali, B. J., Anwar, G. (2021) Innovation: Knowledge Management in the Innovating Industries, 6(3), 10-23. https://dx.doi.org/10.22161/eec.63.2 
[53] Anwar, G., \& Abd Zebari, B. (2015). The Relationship between Employee Engagement and Corporate Social Responsibility: A Case Study of Car Dealership in Erbil, Kurdistan. International Journal of Social Sciences \& Educational Studies, 2(2), 45.

[54] Hamza, P. A., Othman, B. J., Gardi, B., Sorguli, S., Aziz, H. M., Ahmed, S. A., Sabir, B. Y., Ismael, N. B., Ali, B. J., Anwar, G. (2021). Recruitment and Selection: The Relationship between Recruitment and Selection with Organizational Performance. International Journal of Engineering, Business and Management, 5(3), 1-13. https://doi.org/10.22161/ijebm.5.3.1

[55] Anwar, G., \& Shukur, I. (2015). the impact of recruitment and selection on job satisfaction: Evidence from private school in Erbil. International Journal of Social Sciences \& Educational Studies, 1(3), 4-13.

[56] Ali, B. J., Gardi, B., Othman, B. J., Sabir, B. Y., Sorguli, S., Ismael, N. B., Hamza, P.A., Aziz, H. M., Ahmed, A. A., Anwar, G. (2021). The Role of Shopping Malls on Kurdistan Regional Government's Economy. Journal of Humanities and Education Development, 3(3), 39-53. https://doi.org/10.22161/jhed.3.3.5

[57] Anwar, G., \& Shukur, I. (2015). Job satisfaction and employee turnover intention: A case study of private hospital in Erbil. International Journal of Social Sciences \& Educational Studies, 2(1), 73.

[58] Ahmed, S. A., Othman, B. J., Gardi, B., Sabir, B. Y., Ismael, N. B., Hamza, P. A., Sorguli, S., Aziz, H. M., Ali, B. J., Anwar, G. (2021). Students' Attitudes towards Learning English in the Kurdistan region of Iraq. International Journal of English Literature and Social Sciences, 6(3), 072-087. https://doi.org/10.22161/ijels.63.11

[59] Anwar, G., \& Shukur, I. (2015). The Impact of Training and Development on Job Satisfaction: A Case Study of Private Banks in Erbil. International Journal of Social Sciences \& Educational Studies, 2(1), 65.

[60] Ismael, N. B., Othman, B. J., Gardi, B., Hamza, P. A., Sorguli, S., Aziz, H. M., Ahmed, S. A., Sabir, B. Y., Ali, B. J., Anwar, G. (2021). The Role of Training and Development on Organizational effectiveness. International Journal of Engineering, Business and Management, 5(3), 15-24. https://doi.org/10.22161/ijebm.5.3.3 